\title{
The Results of Microbiological Investigations into Preterm Labor
}

\author{
Agamurad A. Orazmuradov, $\mathrm{PhD}, \mathrm{ScD}^{1}$; Igor N. Kostin, $\mathrm{PhD}, \mathrm{ScD}^{1}$; \\ Sergey V. Apresyan, PhD, $\mathrm{ScD}^{1}$; Anna N. Parygina, $\mathrm{PGS}^{1}$; Alexandra A. Gavrilova, $\mathrm{PGS}^{1}$; \\ Gayane A. Arakelyan, PGS ${ }^{1}$; Irina V. Savenkova, PGS ${ }^{1}$; Aleksey A. Lukaev, PhD² \\ ${ }^{1} R U D N$ University, Moscow Russia \\ ${ }^{2}$ Mytishchi City Clinical Hospital Mytishchi, Moscow Region, Russia
}

\begin{abstract}
The purpose of this study was to identify the relationship between the microbiological status of women and newborns, and the development of premature labor.

Materials and Methods: The study included 227 pregnant women at gestational age between 28 and 36 weeks and 6 days. All women underwent an assessment of vaginal microcenosis and the quantitative and qualitative composition of the biotope of the cervical discharge; the newborns underwent bacteriological examination of the auricle, pharynx and anus.

Results: Disturbances in the vaginal biotope were diagnosed in every second woman. We found that the shorter the gestation period, the higher the frequency of disturbances in the vaginal biotope, and the risk of premature birth at an earlier time correlates with the presence of infection in the mother. The risk of giving birth to an infected child is 4.2 times higher at birth from a mother who has disturbances in the biotope, compared to a woman with a normal biotope.(International Journal of Biomedicine. 2019;9(2):144-149.)
\end{abstract}

Key Words: premature labor $\bullet$ vaginal biotope $\bullet$ vaginal infections $\bullet$ newborns

\section{Abbreviations}

PL, premature labor; BG, bacterial growth; GA, gestational age; PB, premature birth.

\section{Introduction}

The causes of spontaneous PL are heterogeneous. An important risk factor for PL is a high infectious index of the genital tract ${ }^{(1,2)}$ during pregnancy and chronic placental insufficiency. ${ }^{(3)}$ The achievements of clinical microbiology in recent decades have largely changed our understanding of the possible causative agents of vaginal infections. ${ }^{(4-9)}$ In women with bacterial vaginosis, PB occurs 3-4 times more often ${ }^{(10)}$ and the likelihood of postpartum endometritis is 5-7 times higher than in women without the infection.

Long-term clinical observations confirm the connection between vaginal infections and adverse pregnancy outcomes

"Corresponding author: Aleksey A. Lukaev, PhD. Mytishchi municipal clinical hospital, Mytishchi, Moscow Region, Russia E-mail:aleksei_lukaev@mail.ru for the mother and fetus. ${ }^{(11-13)}$ To date, convincing evidence of the linkage between vaginal infections and PL, fetal intrauterine infection, and inflammatory complications after childbirth has been published. ${ }^{(14-2)}$ That study, of the reproductive health of the examined women, showed that inflammatory diseases of the body and uterine appendages occurred in $18.2 \%$ of cases. There is evidence of repeated, and often recurrent, inflammatory diseases of the external genital organs and the vagina in $36.9 \%$ of women. ${ }^{(17)}$ Currently, among the infections of the vagina, bacterial vaginosis, aerobic vaginitis and candidal vulvovaginitis play a leading role. ${ }^{(21)}$ Unfavorable predictors of PB are a combination of bacterial vaginosis and the persistence of Ureaplasma urealyticum, Mycoplasma hominis and Mycoplasma genitalium in the cervical canal of pregnant women. ${ }^{(22)}$ Inflammation of the mucous membrane in these cases is due to the activation of various representatives of opportunistic flora. Usually, the pathogens are different 
types of staphylococci and streptococci, enterococci, E. coli, Klebsiella, Proteus and some other bacteria and their associations. $^{(23)}$

However, the development of an imbalance in the vaginal microbiota is still poorly understood. ${ }^{(16,24)}$ Therefore, etiotropic therapy is a difficult task, especially in the early stages of pregnancy. The use of antibacterial drugs during pregnancy is debatable, and treatment approaches do not have solid standards. ${ }^{(25)}$ Numerous clinical studies and systematic reviews based on meta-analysis present conflicting views on antimicrobial therapy for opportunistic infections of the vagina during pregnancy. ${ }^{(26-29)}$ The purpose of this study was to identify the relationship between the microbiological status of women and newborns, and the development of PL.

\section{Materials and Methods}

Our study included 227 pregnant women at gestational age between 28 and 36 weeks and 6 days. Depending on the gestational age, they were divided into 3 groups. Group 1 included 73 women at gestational age between 28 and 30 weeks and 6 days; Group 2 included 81 women at gestational age between 31 and 33 weeks and 6 days, Group 3 included 73 women at gestational age between 34 and 36 weeks and 6 days. All women underwent an assessment of vaginal microcenosis and the quantitative and qualitative composition of the biotope of the cervical discharge; the newborns underwent bacteriological examination of the auricle, pharynx and anus.

In order to study the state of vaginal microcenosis, as well as the diagnosis of trichomonas and gonococcal infections, we performed a microscopic examination of the vaginal discharges, which were taken with a sterile gynecological universal probe (Centrmed LLC, Russia) from the posterior and lateral vaginal vaults. The resulting material was applied to separate areas of a defatted slide, dried in air, and stained with methylene blue or Gram. We then evaluated the leukocyte reaction, the morphology of the microorganisms and their total number, the presence of "key" cells in the vaginal biotope.

To analyze the nature of the quantitative and qualitative composition of the biotope of the cervical discharge, a tamponprobe and test tubes with a transport medium ("Medical Wire \& Equipment", England) were used. Seeding was performed on a series of nutrient media to isolate and cultivate various groups of microorganisms: 5\% blood agar based on Brucella agar with the addition of vitamin growth factors to isolate and cultivate anaerobes, mannitol salt agar to isolate and cultivate gram-negative bacteria, and Saburo medium to isolate and cultivate fungi. Blood agar media were cultivated in a thermostat with a high content of carbon dioxide (5-10\%). To cultivate anaerobes we used anaerostats (Becton Dickinson, USA). The isolated microorganisms were identified and their sensitivity to antibacterial drugs was determined using the Witek bacteriological analyzer.

The results obtained were recorded in accordance with the NCCLS standards (1999-2000). The number of isolated microorganisms was determined by the density of their growth on the sectors of the agar plate.
Bacteriological study of auricular secret and pharynx

The material obtained and transported to the laboratory was seeded on Petri dishes with $5 \%$ blood agar, chocolate agar, and yolk-salt agar, on Endo medium, Saburo medium, and in a tube with glucose broth. Seeding on dense nutrient media was carried out metered (according to Gould), which made it possible to quantify the number of grown colonies. Seedings were incubated at $37^{\circ} \mathrm{C}$ for $24-48$ hours, and were examined daily. Plates with $5 \%$ blood agar were incubated under conditions with a high $\mathrm{CO}_{2}$ content. With the appearance of growth on nutrient media, we counted colonies of various morphologies, taking into account their ratio and species identification of microorganisms, as well as determining their sensitivity to antibacterial drugs. A negative result of the study was issued in the absence of growth on all nutrient media for 72-96 hours.

The study was conducted in accordance with ethical principles of the WMA Declaration of Helsinki (1964, ed. 2013) and approved by the RUDN University Ethics Committee. Written informed consent was obtained from all participants.

Statistical analysis was performed using the Statistica 8.0 software package (StatSoft Inc, USA). Baseline characteristics were summarized as frequencies and percentages for categorical variables and as mean \pm SEM for continuous variables. The Mann-Whitney (U Test) was used to compare the differences between the two independent groups. The Pearson's correlation coefficient (r) and Spearman's rank correlation coefficient $\left(r_{s}\right)$ were was used to determine the strength and direction of the relationship between two variables. The two-proportions z-test was used to compare two observed proportions. Group comparisons with respect to categorical variables are performed using chi-square tests. A value of $P<0.05$ was considered statistically significant.

\section{Results}

Bacterioscopy of the contents of the vaginal and cervical canal contents

According to the results of bacterioscopic examination (Table 1), normocenosis of the genital tract was diagnosed only in $84(37.0 \%)$ women. Disturbances in the vaginal biotope were diagnosed in every second woman. We found that the shorter the gestation period, the higher the frequency of disturbances in the vaginal biotope $(82.2 \%)$. We found a moderate inverse correlation between the term of labor and the presence of bacteria $(\mathrm{r}=-0.3657, P<0.001)$. Significant differences were found between Group 1 and Groups 2 and $3\left(\chi^{2}=23.036\right.$, $P=0.0000)$, and between Groups 2 and $3\left(\chi^{25.653, P=0.017)}\right.$.

Table 1.

The results of bacterioscopic examination

\begin{tabular}{|c|c|c|c|c|c|}
\hline \multirow[t]{2}{*}{ Group } & \multicolumn{2}{|c|}{ normocenosis } & \multicolumn{2}{|c|}{ vaginal infections } & Statistics \\
\hline & $\mathrm{n}$ & $\%$ & $\mathrm{n}$ & $\%$ & \multirow{3}{*}{$\begin{array}{l}\chi^{2}=23.036 \\
P=0.0000\end{array}$} \\
\hline Group $1(n=73)$ & 13 & 17.8 & 60 & 82.2 & \\
\hline Group $2(n-81)$ & 30 & 37.0 & 51 & 63.0 & \\
\hline Group $3(n=73)$ & 41 & 56.2 & 32 & 43.8 & \\
\hline Total $(n=227)$ & 84 & 37.0 & 143 & 63.0 & $P_{1-3}^{2-3}=0.0000$ \\
\hline
\end{tabular}


Table 2.

Bacterial cultures of the cervical canal of pregnant women

\begin{tabular}{|c|c|c|c|c|c|c|c|}
\hline Bacterial cultures & Total & Group 1 & Group 2 & Group 3 & $P_{1-2}$ & $P_{1-3}$ & $P_{2-3}$ \\
\hline E. coli & $27(11.9 \%)$ & $11(15.1 \%)$ & $10(12.3 \%)$ & $6(8.2 \%)$ & 0.6249 & 0.1965 & 0.3979 \\
\hline Candida spp. & $38(16.7 \%)$ & $15(20.5 \%)$ & $13(16 \%)$ & $10(13.7 \%)$ & 0.8389 & 0.5472 & 0.6773 \\
\hline Enterococcus faecalis & $22(9.7 \%)$ & $8(11 \%)$ & $5(6.2 \%)$ & $9(12.3 \%)$ & 0.2924 & 0.7967 & 0.1909 \\
\hline Strep. agalactiae & $8(3.5 \%)$ & $7(9.6 \%)$ & $0(0 \%)$ & $1(1.4 \%)$ & 0.1002 & 0.0281 & 0.7782 \\
\hline Strep. oralis & $7(3.1 \%)$ & $5(6.8 \%)$ & $2(2.5 \%)$ & $0(0 \%)$ & 0.2025 & 0.2515 & 0.6507 \\
\hline Staphyl. epirmidis & $17(7.5 \%)$ & $7(9.6 \%)$ & $9(11.1 \%)$ & $1(1.4 \%)$ & 0.7568 & 0.0281 & 0.0103 \\
\hline Staph.aureus & $15(6.6 \%)$ & $6(8.2 \%)$ & $3(3.7 \%)$ & $6(8.2 \%)$ & 0.2413 & 1.0000 & 0.2413 \\
\hline Staph. haemolyticus & $6(2.6 \%)$ & $2(2.7 \%)$ & $3(3.7 \%)$ & $1(1.4 \%)$ & 0.7346 & 0.5601 & 0.3522 \\
\hline Staph.saprophyticus & $6(2.6 \%)$ & $2(2.7 \%)$ & $4(4.9 \%)$ & $0(0 \%)$ & 0.4755 & 0.6195 & 0.3874 \\
\hline Gemella morbillorum & $1(0.4 \%)$ & $0(0 \%)$ & $1(1.2 \%)$ & $0(0 \%)$ & 0.8163 & 1.0000 & 0.8163 \\
\hline Enterobacter aerogenes & $3(1.3 \%)$ & $2(2.7 \%)$ & $1(1.2 \%)$ & $0(0 \%)$ & 0.5084 & 0.6195 & 0.8163 \\
\hline Strep.viridans & $3(1.3 \%)$ & $1(1.4 \%)$ & $1(1.2 \%)$ & $1(1.4 \%)$ & 0.9412 & 1.0000 & 0.9412 \\
\hline Staph. warneri & $1(0.4 \%)$ & $0(0 \%)$ & $1(1.2 \%)$ & $0(0 \%)$ & 0.8163 & 1.0000 & 0.8163 \\
\hline Serratia odorifera & $1(0.4 \%)$ & $0(0 \%)$ & $1(1.2 \%)$ & $0(0 \%)$ & 0.8163 & 1.0000 & 0.8163 \\
\hline Enterobacter cloacae & $1(0.4 \%)$ & $1(1.4 \%)$ & $0(0 \%)$ & $0(0 \%)$ & 0.7782 & 0.7979 & 1.0000 \\
\hline Streptococcus mitis & $3(1.3 \%)$ & $0(0 \%)$ & $2(2.5 \%)$ & $1(1.4 \%)$ & 0.6507 & 0.7979 & 0.6174 \\
\hline Corynebacterium spp. & $4(1.8 \%)$ & $1(1.4 \%)$ & $2(2.5 \%)$ & $1(1.4 \%)$ & 0.6174 & 1.0000 & 0.6174 \\
\hline Acinetobacter & $6(2.6 \%)$ & $1(1.4 \%)$ & $2(2.5 \%)$ & $3(4.1 \%)$ & 0.6174 & 0.3106 & 0.5716 \\
\hline Klebsiella pneumoniae & $1(0.4 \%)$ & $0(0 \%)$ & $0(0 \%)$ & $1(1.4 \%)$ & 1.0000 & 0.7979 & 0.7782 \\
\hline
\end{tabular}

Table 3.

Data of bacteriological results from the studied loci (the anus. ears and pharynx) in newborns

\begin{tabular}{|c|c|c|c|c|c|c|c|}
\hline Bacterial cultures & Total & Group 1 & Group 2 & Group 3 & $P_{1-2}$ & $P_{1-3}$ & $P_{2-3}$ \\
\hline E.coli & $20(8.8 \%)$ & $9(12.3 \%)$ & $8(9.9 \%)$ & $3(4.1 \%)$ & 0.6299 & 0.0695 & 0.1563 \\
\hline Candida spp & $9(4 \%)$ & $5(6.8 \%)$ & $3(3.7 \%)$ & $1(1.4 \%)$ & 0.3869 & 0.0944 & 0.3522 \\
\hline Enteroccocus faecalis & $20(8.8 \%)$ & $8(11 \%)$ & $5(6.2 \%)$ & $7(9.6 \%)$ & 0.2924 & 0.7855 & 0.4347 \\
\hline Enterobacter cloacae & $1(0.4 \%)$ & $0(0 \%)$ & $1(1.2 \%)$ & $0(0 \%)$ & 0.8163 & 1.0000 & 0.8163 \\
\hline Strep.agalactiae & $9(4 \%)$ & $4(5.5 \%)$ & $4(4.9 \%)$ & $1(1.4 \%)$ & 0.8804 & 0.1716 & 0.1988 \\
\hline Strep.oralis & $5(2.2 \%)$ & $2(2.7 \%)$ & $1(1.2 \%)$ & $2(2.7 \%)$ & 0.5084 & 1.0000 & 0.5084 \\
\hline Streptococcus mitis & $2(0.9 \%)$ & $0(0 \%)$ & $1(1.2 \%)$ & $1(1.4 \%)$ & 0.8163 & 0.7979 & 0.9412 \\
\hline Staph. aureus & $18(7.9 \%)$ & $8(11 \%)$ & $7(8.6 \%)$ & $3(4.1 \%)$ & 0.6306 & 0.1160 & 0.2460 \\
\hline Staph. saprophyticus & $3(1.3 \%)$ & $2(2.7 \%)$ & $1(1.2 \%)$ & $0(0 \%)$ & 0.5084 & 0.6195 & 0.8163 \\
\hline Staph. epirmidis & $15(6.6 \%)$ & $8(11 \%)$ & $5(6.2 \%)$ & $2(2.7 \%)$ & 0.2924 & 0.0482 & 0.2979 \\
\hline Staph. haemolyticus & $4(1.8 \%)$ & $3(4.1 \%)$ & $0(0 \%)$ & $1(1.4 \%)$ & 0.4313 & 0.3106 & 0.7782 \\
\hline Staph. warneri & $3(1.3 \%)$ & $2(2.7 \%)$ & $1(1.2 \%)$ & $0(0 \%)$ & 0.5084 & 0.6195 & 0.8163 \\
\hline Strep. viridans & $1(0.4 \%)$ & $0(0 \%)$ & $0(0 \%)$ & $1(1.4 \%)$ & 1.0000 & 0.7979 & 0.7782 \\
\hline Neisseria spp. & $10(4.4 \%)$ & $3(4.1 \%)$ & $5(6.2 \%)$ & $2(2.7 \%)$ & 0.5611 & 0.6495 & 0.2979 \\
\hline Genella morbillorum & $1(0.4 \%)$ & $1(1.4 \%)$ & $0(0 \%)$ & $0(0 \%)$ & 0.7782 & 0.7979 & 1.0000 \\
\hline Serratia marcescens & $4(1.8 \%)$ & $3(4.1 \%)$ & $1(1.2 \%)$ & $0(0 \%)$ & 0.2756 & 0.4691 & 0.8163 \\
\hline Serratia odorifera & $1(0.4 \%)$ & $0(0 \%)$ & $1(1.2 \%)$ & $0(0 \%)$ & 0.8163 & 1.0000 & 0.8163 \\
\hline Corynebacterium spp. & $3(1.3 \%)$ & $0(0 \%)$ & $1(1.2 \%)$ & $2(2.7 \%)$ & 0.8163 & 0.6195 & 0.5084 \\
\hline Acinebacter & $1(0.4 \%)$ & $1(1.4 \%)$ & $0(0 \%)$ & $0(0 \%)$ & 0.7782 & 0.7979 & 1.0000 \\
\hline Klebsiella pneumoniae & $2(0.9 \%)$ & $2(2.7 \%)$ & $0(0 \%)$ & $0(0 \%)$ & 0.5873 & 0.6195 & 1.0000 \\
\hline
\end{tabular}


The study of cervical canal cultures

In all pregnant women $(\mathrm{n}=227)$, immediately upon admission to the hospital, a discharge content from the cervical canal was taken for bacteriological examination with the determination of sensitivity to antibacterial drugs. The data of the first seeding are the most important, since after the course of antibiotic therapy, the subsequent results of bacteriological seeding are uninformative for the diagnosis of vaginal microflora. The growth of microorganisms was observed in $143(63.0 \%)$ pregnant women; in 29(12.8\%) women who gave birth, the growth of the bacterial flora in the newborns was not observed.

The leading positions among the sowed microorganisms were occupied by Candida spp. (38/16.7\%), E. coli $(27 / 11.9 \%)$, and Enterococcus faecalis (22/9.7\%), and the growth of 50\% of the detected bacteria was observed in Group 1 (Table 2). In bacterial vaginosis, microorganisms of intestinal origin were predominant against the background of a significant decrease in the frequency of lactobacilli. In vaginitis, associations of microorganisms represented by $2-5$ species with an anaerobic or aerobic component were found in all cases. At the same time, 84 women with normal flora gave birth to $16(28.6 \%)$ children, who showed bacterial growth in diagnostically significant titers. Thus, respectively, only $68(30 \%)$ of the women gave birth to children who did not show an increase in bacterial opportunistic flora.

All newborns were bacteriologically examined (the anus, ears and pharynx). The growth of microorganisms was observed in 131(57.7\%) newborns (Table 3). The leading positions among the sowed microorganisms in children were occupied by E. coli (20/8.8\%), Enteroccocus faecalis (20/8.8\%), Candida spp. (9/4\%), and Streptococcus agalactiae (9/4\%). At the same time, the growth of microflora was found significantly more often in newborns from mothers of Group 1. According to the study, in $127(55.9 \%)$ of 227 children, the growth of bacteria from the studied loci was detected in diagnostically significant titers $\left(>10^{5} \mathrm{cfu} / \mathrm{ml}\right)$. At the same time, in $114(89.8 \%)$ of these children, the growth of microflora was associated with the identified infection in mothers (Table 4, Fig.1). The birth of a child with microorganisms correlated with the presence of infection in the mother $\left(\mathrm{r}_{\mathrm{s}}=0.706, P<0.0001\right)$.

\section{Table 4.}

Comparative analysis of bacterial growth in women and newborns

\begin{tabular}{|l|c|c|c|c|c|c|c|}
\hline & $\begin{array}{c}\text { Total } \\
(\mathrm{n} / \%)\end{array}$ & $\begin{array}{c}\text { Group 1 } \\
(\mathrm{n} / \%)\end{array}$ & $\begin{array}{c}\text { Group 2 } \\
(\mathrm{n} / \%)\end{array}$ & $\begin{array}{c}\text { Group 3 } \\
(\mathrm{n} / \%)\end{array}$ & $P_{1-2}$ & $P_{1-3}$ & $P_{2-3}$ \\
\hline BG in women & $143 / 63$ & $60 / 82.2$ & $51 / 63$ & $32 / 43.8$ & 0.007 & 0.000 & 0.017 \\
\hline BG in newborns & $127 / 55.9$ & $54 / 74$ & $43 / 53.1$ & $30 / 41.1$ & 0.006 & 0.000 & 0.136 \\
\hline $\begin{array}{l}\text { BG in women } \\
\text { and newborns }\end{array}$ & $114 / 50.2$ & $50 / 68.5$ & $38 / 46.9$ & $26 / 35.6$ & 0.006 & 0.000 & 0.154 \\
\hline $\begin{array}{l}\text { BG in women, } \\
100 \%\end{array}$ & 143 & 60 & 51 & 32 & & & \\
\hline $\begin{array}{l}\text { The proportion } \\
\text { of newborns } \\
\text { with BG in \% of } \\
\text { mothers with BG }\end{array}$ & $114 / 79.7$ & $50 / 83.3$ & $38 / 74.5$ & $26 / 81.3$ & 0.259 & 0.805 & 0.466 \\
\hline
\end{tabular}

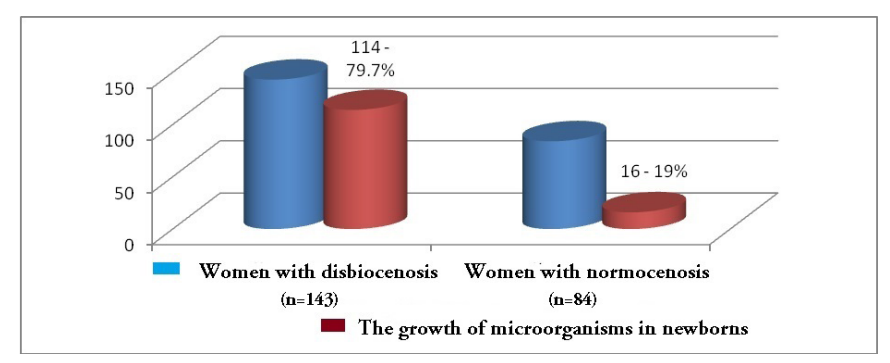

Fig. 1. Bacterial growth in women and newborns.

\section{Discussion}

High contamination of the genital tract of pregnant women with opportunistic and pathogenic bacterial and viral microflora is a high risk factor for PB. It is noted that the shorter the gestation period, the higher the frequency of disturbances in the vaginal biotope (82.2\%), and the risk of PB at an earlier time correlates with the presence of infection in the mother ( $\left.\mathrm{r}=-0,327, P<0.001 ; \mathrm{r}_{\mathrm{s}}=-0.331, P=0.004\right)$ (Fig.2). The study by D. Nelson ${ }^{(16)}$ showed that the prevalence of bacterial vaginosis among pregnant women was $3.88 \%$, and the presence of $\mathrm{G}$. vaginalis was $67.48 \%$; but the presence of $\mathrm{G}$. vaginalis was not enough to cause bacterial vaginosis. However, the presence of G. vaginalis may be considered a significant risk factor for $\mathrm{PB}$.

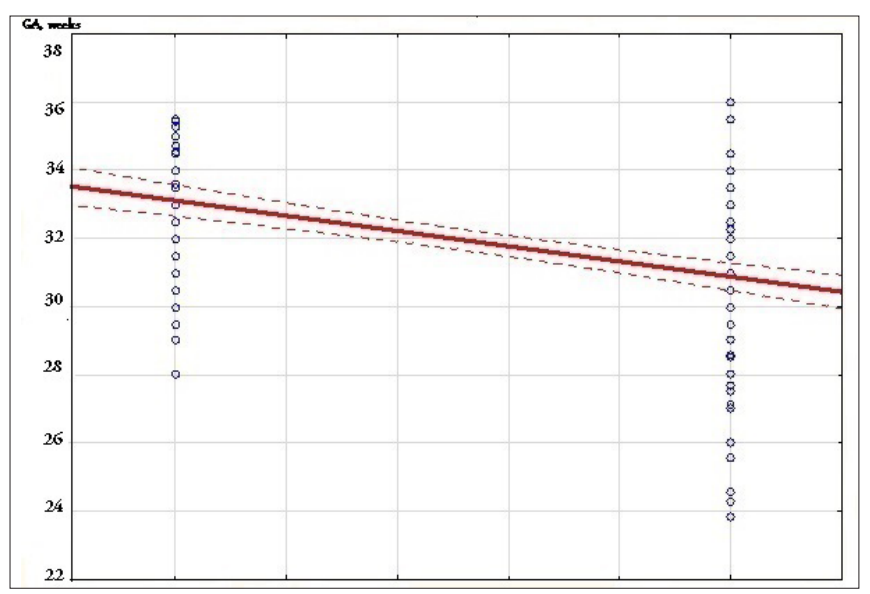

Fig.2. The growth of microorganisms in the cervical canal of pregnant women $(r=-0.327, P<0.001 ; O R=4.19,95 \%$ CI: $2.67-6.55)$

In the previous study, ${ }^{(17)}$ we showed the main risk factors leading to PL: early sexual debut, inflammatory diseases of the urinary organs, sexually transmitted infections, reproductive losses in history, anemia, etc. The present study shows the association of PL with an infectious factor. In our opinion, and according to a number of authors, a high bacterial contamination of the genital tract, already at the stage prior to the onset of pregnancy, contributes to the infection of the fetal membranes, with impaired amniotic fluid production, starting from the early stages of gestation.

Comparing the data obtained with the results of neonatal outcomes, according to a previous study, ${ }^{(30)}$ we can note the 
high risk of having children with congenital pneumonia in women of Group 1. With an increase in the period of gestation, the frequency of this complication is significantly reduced. In the future, we plan to perform a placental histology study and identify the presence of possible relationships among the data of microbiological studies.

\section{Conclusion}

The risk of giving birth to an infected child is 4.2 times higher at birth from a mother who has disturbances in the biotope, compared to a woman with a normal biotope. The result is a long-term presence of the newborn in the intensive care unit, antibiotic therapy, and a long rehabilitation period. Despite the ongoing preventive antibiotic therapy in pregnant women and mothers, the frequency of detectable pathogenic microorganisms in newborns has not decreased. The data obtained are explainable from several positions:

- First, microorganisms are resistant to antibacterial drugs used.

- Second, and probably the most important:Acontamination of the newborn with pathogenic microorganisms occurs in-utero (prenatally) at earlier gestational periods.

In our study, 7(3.4\%) women showed resistance to antibacterial drugs during bacteriological examination of discharge content from the cervical canal: E. coli was found in 5 women and Staphylococcus epidermidis in 2 women.

Thus, the results of the study allow us to:

- identify the group of pregnant women at risk for the infection process

- carry out therapeutic measures for the prevention and treatment of microflora biocenosis disorders in the early stages of gestation, and

- carry out measures to improve the reproductive potential of the population.

\section{Competing Interests} interests.

The authors declare that they have no competing

\section{Sources of Funding}

The study was supported by the RUDN University Program 5-100.

\section{References}

1. Khadartseva KA, Kusibaeva RK. [The role of pregravid preparation in improving perinatal outcomes in women with inflammatory diseases of the genital tract]. Russian Journal of Woman and Child Health. 2017;(25):1934-1937. [Article in Russian].

2. Dolgushina VF, Kurnosenko IV, Astashkina MV, Nadvigova TV. [Infectious Pathology of the vagina and the cervix in women with spontaneous preterm birth]. Ural medical journal. 2017;(1):62-64. [Article in Russian].

3. Katkova NYu, Bodrikova OI, Bezrukova IM, Guseva OI, Lebedeva NV, Pokusayeva KB, Mikhaylenko OA. [Clinical and Anamnestic Features of Different Types of Premature Birth (Retrospective Review)]. Effektivnaya Farmakoterapiya. 2017; (26):12-17. [Article in Russian].

4. Beghini J, Giraldo PC, Linhares IM, Ledger WJ, Witkin SS. Neutrophil Gelatinase-Associated Lipocalin Concentration in Vaginal Fluid: Relation to Bacterial Vaginosis and Vulvovaginal Candidiasis. Reprod Sci. 2015;22(8):964-8. doi: $10.1177 / 1933719115570914$.

5. HilbertDW, Smith WL, Chadwick SG, Toner G, Mordechai E, Adelson ME, et al. Development and Validation of a Highly Accurate Quantitative Real-Time PCR Assay for Diagnosis of Bacterial Vaginosis. J Clin Microbiol. 2016;54(4):1017-24. doi: 10.1128/JCM.03104-15.

6. Vieira-Baptista P, Lima-Silva J, Pinto C, Saldanha C, Beires J, Martinez-de-Oliveira J, Donders G. Bacterial vaginosis, aerobic vaginitis, vaginal inflammation and major Pap smear abnormalities. Eur J Clin Microbiol Infect Dis. 2016;35(4):657-64. doi: 10.1007/s10096-016-2584-1.

7. Vitali B, Cruciani F, Picone G, Parolin C, Donders G, Laghi L. Vaginal microbiome and metabolome highlight specific signatures of bacterial vaginosis. Eur J Clin Microbiol Infect Dis. 2015;34(12):2367-76. doi: 10.1007/s10096-0152490-y.

8. Wang ZL, Fu LY, Xiong ZA, Qin Q, Yu TH, Wu YT, et al. Diagnosis and microecological characteristics of aerobic vaginitis in outpatients based on preformed enzymes. Taiwan J Obstet Gynecol. 2016;55(1):40-4. doi: 10.1016/j. tjog.2015.06.012.

9. Xiao B, Niu X, Han N, Wang B, Du P, Na R, et al. Predictive value of the composition of the vaginal microbiota in bacterial vaginosis, a dynamic study to identify recurrencerelated flora. Sci Rep. 2016;6:26674. doi: 10.1038/srep26674. 10. Petrov YuA, Galushchenko EM, Arndt IG. [Premature birth taking into account the influence of the vaginal microbiocenosis]. Mezhdunarodnii Zhurnal Prikladnih i Fundamental'nih Sssledovanii. 2018;(11-2):384-388. [Article in Russian].

11. Radzinsky VE, Orazmuradov AA. Early gestational age. From pregravid preparation to healthy gestation. 3rd., rev. version. M.: StatusPraesens; 2018. [In Russian].

12. Subramaniam A, Kumar R, Cliver SP, Zhi D, Szychowski JM, Abramovici A, et al. Vaginal Microbiota in Pregnancy: Evaluation Based on Vaginal Flora, Birth Outcome, and Race. Am J Perinatol. 2016;33(4):401-8. doi: 10.1055/s-00351565919.

13. Yang S, Reid G, Challis JR, Kim SO, Gloor GB, Bocking $\mathrm{AD}$. Is there a role for probiotics in the prevention of preterm birth? Front Immunol. 2015;6:62. doi: 10.3389/ fimmu.2015.00062.

14. Haahr T, Ersbøll AS, Karlsen MA, Svare J, Sneider K, Hee $\mathrm{L}$, et al. Treatment of bacterial vaginosis in pregnancy in order to reduce the risk of spontaneous preterm delivery - a clinical recommendation. Acta Obstet Gynecol Scand. 2016;95(8):850-60. doi: 10.1111/aogs.12933.

15. Heczko PB, Tomusiak A, Adamski P, Jakimiuk AJ, Stefański G, Mikołajczyk-Cichońska A, et al. Supplementation of standard antibiotic therapy with oral probiotics for bacterial vaginosis and aerobic vaginitis: a randomised, double-blind, placebo-controlled trial. BMC Womens Health. 2015;15:115. doi: 10.1186/s12905-015-0246-6.

16. Nelson DB, Hanlon AL, Wu G, Liu C, Fredricks DN. First Trimester Levels of BV-Associated Bacteria and Risk of Miscarriage Among Women Early in Pregnancy. Matern Child 
Health J. 2015;19(12):2682-7. doi: 10.1007/s10995-015-1790-2. 17. Orazmuradov AA, Soyunov MA, Efendieva ZM, Lukaev AA, Gradova IE, Mukhtarova AV, Kaplina IN. Influence of Perinatal Risk Factors on Premature Labor Outcome. International Journal of Biomedicine. 2016;6(3):199-201

18. Kuzmina TE, Pashkov VM, Klindukhov I.A. [Pregravid preparation. Modern conceptions]. Gynecology, Obstetrics and Perinatology. 2015;14(5):47-54. [Article in Russian]. 19. Pustotina OA, Akhmedova AE. [Pregravid preparation for women with a history of miscarriage]. Meditsinskiy Sovet. 2016;(4):130-136. [Article in Russian].

20. Khamadyanov UR, Gumerova IA, Khamadyanova AU, Galimov AI, Khamadyanova SU, Tikhonova TF. [Role of genital nontransmissible infections in preterm pregnancy termination]. Russian Bulletin of Obstetrician-Gynecologist. 2016;16(6):32-37. [Article in Russian].

21. Karapetyan TE, Muraveva VV, Ankirskaya AS, Lyubasovskaya LA, Priputnevich TV. [Treatment options for opportunistic vaginal infections during pregnancy]. Ginekologiia. 2017;19(6):11-15. [Article in Russian].

22. Radzinskiy VE, Orazmuradov AA, Arakelyan VF. [Biocenosis vagina at the very early preterm labor]. Medical Herald of the South of Russia. 2014;(4):90-94. [Article in Russian].

23. Tyutyunnik VL, Kan NE, Lomova NA. [Modern aspects of therapy of non-specific vulvovaginitis during pregnancy]. Meditsinskiy Sovet. 2018;(7):102-105. [Article in Russian].
24. Nasioudis D, Linhares IM, Ledger WJ, Witkin SS Bacterial vaginosis: a critical analysis of current knowledge. BJOG. 2017;124(1):61-69. doi: 10.1111/1471-0528.14209.

25. Podgornaya AV, Makhmutkhodzhaev ASh, Mikheenko GA, Koch LI. [Management of pregnant women with recurrent bacterial vaginosis]. Modern problems of science and education. 2016(6):172. [Article in Russian].

26. Amaya-Guio J, Viveros-Carreño DA, Sierra-Barrios EM, Martinez-Velasquez MY, Grillo-Ardila CF. Antibiotic treatment for the sexual partners of women with bacterial vaginosis. Cochrane Database Syst Rev. 2016;10:CD011701. 27. Catallozzi M, Fraiz LD, Hargreaves KM, Zimet GD, Stanberry LR, Ratner AJ, et al. Pregnant women's attitudes about topical microbicides for the prevention and treatment of bacterial vaginosis during pregnancy. Int J STD AIDS. 2017;28(9):881-886. doi: 10.1177/0956462416679067.

28. Liang Q, Li N, Song S, Zhang A, Li N, Duan Y. High-dose nifuratel for simple and mixed aerobic vaginitis: A singlecenter prospective open-label cohort study. J Obstet Gynaecol Res. 2016;42(10):1354-1360. doi: 10.1111/jog.13052.

29. Sobel R, Sobel JD. Metronidazole for the treatment of vaginal infections. Expert Opin Pharmacother. 2015;16(7):1109-15. doi: 10.1517/14656566.2015.1035255.

30. Orazmuradov AA, Zakharova NI, Lukaev AA, Zholobova EV. Neonatal outcomes in the postpartum period depending on perinatal risk factors, terms and mode of delivery. International Journal of Biomedicine. 2016;6(3):202-206. 